\title{
Effects of offshore tuna farming on benthic assemblages in the Eastern Mediterranean
}

\author{
Manolis Moraitis ${ }^{1}$, Nafsika Papageorgiou ${ }^{1}$, Panagiotis D. Dimitriou ${ }^{1}$, \\ Antonis Petrou ${ }^{2}$, Ioannis Karakassis ${ }^{1, *}$
}

${ }^{1}$ Marine Ecology Laboratory, Department of Biology, University of Crete, PO Box 2208, 71409 Heraklion, Crete, Greece ${ }^{2}$ AP Marine Environmental Consultancy Ltd., PO Box 26728, 1647 Nicosia, Cyprus

\begin{abstract}
The spatial effects of 2 tuna farms on the benthic community were investigated in the Eastern Mediterranean during the fattening period. The impact on benthic fauna was assessed in the vicinity of the fish farms (beneath and at various distances from the cages) using a variety of benthic indicators used for the implementation of the EU Water Framework Directive (WFD). There was a general consensus that most of the samples (95\%) were acceptable, i.e. of 'good' or 'high' ecological status. The biotic indices were also compared between 2 different mesh sizes, total (resulting from the sum of the fractions of 1 and $0.5 \mathrm{~mm}$ mesh fractions) and $1 \mathrm{~mm}$ mesh, in order to assess the variability of the results. The indicators showed the same pattern between the 2 different sieve mesh sizes. The variability in the ecological status assigned by each indicator was also examined among the replicates taken from each station. Our results showed that one replicate is not sufficient for monitoring purposes, and we suggest obtaining more replicates while using indicators requiring less taxonomic effort for sample processing. Neither fish farm had a significant impact on benthic communities, due mainly to the exposed nature of the study site.
\end{abstract}

KEY WORDS: Tuna farming - Aquaculture impact - Benthic indicators - Benthic communities · Sieve mesh size $\cdot$ Replicate variability

\section{INTRODUCTION}

Atlantic bluefin tuna Thunnus thynnus is one of the most sought-after and expensive tuna species in the fish market (Ottolenghi 2008). Since the mid 1990s, the expansion of tuna farming in the Mediterranean Sea has been accompanied by widespread concerns about the environmental impact of this thriving industry. The effects of capturebased aquaculture of bluefin tuna have been examined by a limited number of studies (Cheshire et al. 1996, Madigan et al. 2001, Santulli et al. 2003, Vita et al. 2004, 2007a,b, Matijević et al. 2006, Vita \& Marin 2007, Vezzulli et al. 2008, Aksu et al. 2010, Forrestal et al. 2012) which have considered the environmental sustainability of this type of farming.

${ }^{*}$ Corresponding author. Email: karakassis@biology.uoc.gr
Tuna farming is based on fattening the fish after capture in the wild to increase both their overall size and improve the oil/fat content of the flesh (Aksu et al. 2010). This period lasts from 4 to 8 mo (usually from June to December) and is carried out in large floating cages. The farmed fish are mainly fed previously frozen sardines, anchovies, mackerel, cuttlefish and herring (Başaran \& Özden 2004) with a daily feed rate of approximately 5 to $8 \%$ of body biomass (FAO 2004). The main environmental concern derived from this 'fattening' activity is the unknown impact of uneaten food and metabolic wastes (Vezzulli et al. 2008). Many studies have highlighted these aquaculture by-products as the main cause of negative environmental impacts from aquaculture (Gowen et al. 1991, Karakassis et al. 2000, Vezzulli et al. 2002, 2003, $2004,2008)$. Organic enrichment of the sediment as-

() The authors 2013. Open Access under Creative Commons by Attribution Licence. Use, distribution and reproduction are unrestricted. Authors and original publication must be credited. 
sociated with cage fish farming and the resultant impact on the benthic communities due to the accumulation of particulate matter in the vicinity of the net cages has been widely documented (Holby \& Hall 1991, Karakassis et al. 2000, Vezzulli et al. 2002, 2003, 2004). The intensity of the impact depends on the species, farming method, feeding type and the nature of the receiving environment in terms of physics, chemistry and biology (Wu 1995). The effects of bluefin tuna farming could be expected to be greater than other types of fish farming, an assumption derived from the fact that this type of farming has a very high reared biomass and a high feed conversion ratio (range 20:1 to 30:1), as whole bait fish are used for feeding. (Vezzulli et al. 2008, Aksu et al. 2010).

Macrobenthic communities have been used for decades as an indicator of sediment condition in the environmental monitoring of anthropogenic activities (Gray 1981). The suitability of benthic organisms as indicators of stress is based on the fact that their communities reflect the effects of sediment impact over a long period of time, their vital role in nutrient circulation between the underlying sediment and the overlying water column, and the fact that they are relatively sedentary organisms and so unable to avoid deteriorating environmental conditions (Gray et al. 1988, Borja et al. 2000, Dauvin \& Ruellet 2007, de-la-Ossa-Carretero et al. 2012). The changes in the seabed community structure as a result of discharge of fish farm wastes follow the succession pattern of response to organic enrichment gradient introduced by Pearson \& Rosenberg (1978); thus macrofauna should be included in monitoring studies of the environmental effects of fish farming (Apostolaki et al. 2007). Previous studies of the spatial effects of coastal fish farming on macrofauna showed that the impact is readily detectable up to $25 \mathrm{~m}$ from the edge of the cages (Karakassis 2001, Lampadariou et al. 2005, Papageorgiou et al. 2010), while the severity of this impact is determined by various factors such as the sediment type and local water currents (Karakassis 2001). Although there is a significant amount of information on the effects of coastal fish farming, knowledge of the environmental impacts of offshore aquaculture is very limited (Holmer 2010). There is no universal consensus as to the definition of 'offshore', but Holmer (2010) uses a series of criteria to distinguish between 'coastal', 'off coast' and 'offshore' including e.g. distance $(<0.5,0.5$ to 3 , and $>3 \mathrm{~km}$, respectively), depth $(<10,10$ to 50 , and $>50 \mathrm{~m})$, exposure (sheltered, partly sheltered, exposed), and wave height. Offshore farming is considered advantageous for both the fish farms and the environment due to higher water quality resulting from the exposed situation in offshore locations; therefore, it is regarded as a means to overcome the problems associated with coastal fish farming (Vezzulli et al. 2008).

The European Water Framework Directive 2000/ 60/EC (WFD), requires that all European water bodies should achieve a good ecological status (ES) by 2015. In this context, a variety of biotic indicators have been proposed as tools for assessing the ecological quality of the benthic environment. In the Mediterranean ecoregion, the most commonly used indicators are M-AMBI (Multivariate AZTI's Marine Biotic Index; Muxika et al. 2007) and BENTIX (Simboura \& Zenetos 2002). ES is defined according to reference values of these biotic indices (Labrune et al. 2006, Dimitriou et al. 2012). Although the majority of the macrobenthic benthic indices rely on a species-based taxonomy, several studies suggest the use of higher taxonomic levels in routine environmental and pollution monitoring programs (Warwick 1988, Ferraro \& Cole 1990, Olsgard et al. 1997, de-la-OssaCarretero et al. 2012, Dimitriou et al. 2012). Thompson et al. (2003) suggest that the impacts of increasing stress are accumulated at increasingly higher taxonomic levels, based on the 'hierarchical response to stress' hypothesis. Consequently the Benthic Quality Index at the family level, (BQI-family; Dimitriou et al. 2012) can be a useful higher order approach.

Evaluating the macrofaunal community structure for a monitoring program is time-consuming, and expensive, in terms of both sampling effort in the field and laboratory analysis (Thompson et al. 2003). In studies of marine macrofauna, sediment samples are usually sieved through a 0.5 or $1 \mathrm{~mm}$ mesh (e.g. Lampadariou et al. 2005). Although the use of a $0.5 \mathrm{~mm}$ mesh sieve retains more fauna (hence, it potentially provides more information regarding the community structure), it requires considerably more time and effort for sorting and identification of the organisms than a $1 \mathrm{~mm}$ mesh sieve (Couto et al. 2010). Many benthic pollution monitoring studies suggest the use of a $1 \mathrm{~mm}$ mesh sieve mainly for 2 reasons: (1) the minor loss of information in relation to the $0.5 \mathrm{~mm}$ mesh sieve does not compromise the data reliability in terms of detecting anthropogenic impacts, and (2) the coarser sieves require less time for sorting and identification, thus reducing the overall cost of the monitoring program (Hartley 1982, Karakassis \& Hatziyanni 2000, Lampadariou et al. 2005). However, most of abovementioned studies have assessed the information loss through the effect of taxonomic resolution on the results of multivariate analyses, but not on the use of the ES indicators. 
Sample size (in terms of replicates) can also affect both the cost and the time required for processing; therefore, a reduction in sample size is always welcome (Mavrič et al. 2013). The WFD stipulates that sampling procedures must provide a dataset that reflects the composition and abundance of the benthic invertebrate fauna. Therefore, as with sieving, caution is needed when reducing the number of replicates because this can affect the metric output. Even though many studies have addressed this issue (e.g. Vlek et al. 2004, Fleischer et al. 2007), very few of the methodologies used in the WFD present information on the robustness of their metrics or on the accuracy and variation of the results obtained (Borja et al. 2008, Mavrič et al. 2013).

Cyprus has adopted a consistent strategy for fish farming since the onset of the industry in the 1990s, allowing the establishment of fish farms only at deep $(>30 \mathrm{~m})$ exposed sites at a distance of $>1$ mile offshore. The sites for fish farms (including tuna farming) are selected by the authorities and rented to companies/beneficiaries, who are obliged to carry out regular monitoring of a range of environmental variables.

The aims of the present study were: (1) to evaluate the spatial effect of tuna farming on the coasts of Cyprus, using a variety of indicators, some of them used for the assessment of environmental quality in the WFD; (2) to test the hypothesis that there is no difference between results obtained using different sieve mesh sizes for the analysis of benthic fauna; and (3) to assess the variability of different indicators among replicates obtained from the same sampling station.

\section{MATERIALS AND METHODS}

\section{Study site}

The study was conducted in Limassol Bay (south coast of Cyprus, Eastern Mediterranean) during the ongrowing/fattening period of 2 marine fish farms (Fig. 1) This investigation included 7 sampling stations at 2 tuna fattening farms (codenamed TT and KIT). The fish farms were located at $1.33 \mathrm{~km}$ (KIT) and $2 \mathrm{~km}$ (TT) distance from the coast. Each farm consisted of six $50 \mathrm{~m}$ diameter round cages with volumes ranging from 4000 to $4500 \mathrm{~m}^{3}$. The study area was characterized by muddy-sand substrate and the current velocity ranged from 10 to $35 \mathrm{~cm} \mathrm{~s}^{-1}$. In the coastal zone adjacent to the farming sites, anthropogenic activities include a small cement factory, a port, and

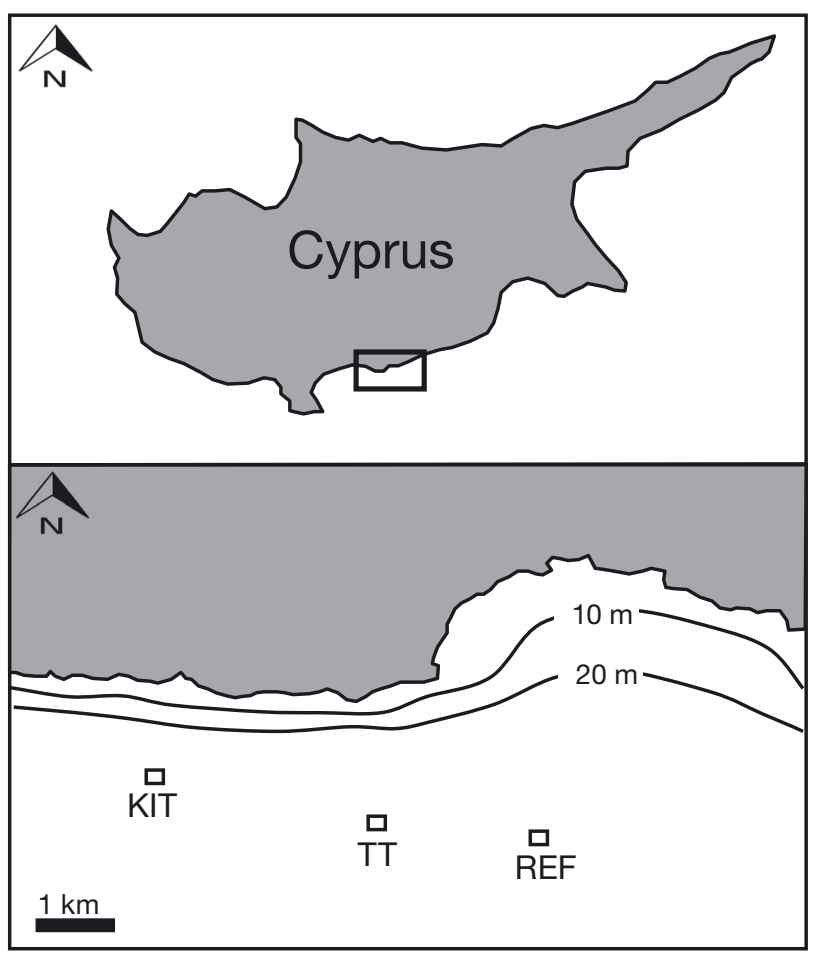

Fig. 1. Study area in Limassol Bay (south coast of Cyprus, Eastern Mediterranean). Sampling stations were located at 2 tuna fattening farms, codenamed TT (34 $\left.41^{\prime} 27^{\prime \prime} \mathrm{N}, 33^{\circ} 15^{\prime} 54^{\prime \prime} \mathrm{E}\right)$, KIT $\left(34^{\circ} 41^{\prime} 41^{\prime \prime} \mathrm{N}, 33^{\circ} 14^{\prime} 06^{\prime \prime} \mathrm{E}\right)$ and at a reference station (REF), $2 \mathrm{~km}$ from the nearest farm $\left(34^{\circ} 41^{\prime} 32^{\prime \prime} \mathrm{N}, 33^{\circ} 17^{\prime} 13^{\prime \prime} \mathrm{E}\right)$

navigation and agricultural activities. Tourism sites in the vicinity are located $\sim 4 \mathrm{~km}$ from the sampling stations and we have no reason to assume that activities there affected the study area at all.

\section{Sampling}

The fattening period started in June and ended in October 2009. The samples were collected from the 2 fish farms in September 2009. At each fish farm, 1 sampling station was located under the cages (stations codenamed TT and KIT) and 2 further stations were located at 50 and $250 \mathrm{~m}$ distance from the cages (TT 50, TT 250, KIT 50 and KIT 250). A reference station (REF) was used to sample undisturbed conditions. The reference station was located $2 \mathrm{~km}$ from the nearest fish farm (TT), and $3.7 \mathrm{~km}$ off the coast (Fig. 1). The sediment characteristics and the hydrodynamic regime at the reference station were the same as at the other stations. The sampling positions were selected to provide information on gradients of impact. It was assumed that maximum impact would 
occur at the stations under the cages and minimum impacts at the reference station. Sampling depths at each station are presented in Table 1.

At each station, 3 grab (Van Veen $0.1 \mathrm{~m}^{2}$ ) replicates were collected for macrofauna sampling, on mainly muddy-sand sediment bottom and each of the replicates was sieved first with a $1 \mathrm{~mm}$ and then a $0.5 \mathrm{~mm}$ mesh sieve. The sieved samples were fixed with $10 \%$ formalin and transferred to the laboratory for sorting and identification. The organisms were stained using the organic colouring substance Rose Bengal and after sorting were identified to species level where possible (i.e. in most cases) and otherwise to the lowest possible taxonomic level.

Data analysis was undertaken independently for both groups of sieved data. The 'total sieve' classification refers to the fraction resulting from the sum of the $1 \mathrm{~mm}$ and $0.5 \mathrm{~mm}$ mesh fractions, whereas the ' $1 \mathrm{~mm}$ sieve' classification refers to the macrofauna retained only by the $1 \mathrm{~mm}$ mesh sieve.

\section{Biotic indices}

A variety of benthic biological indices were calculated in order to assess the ecological status (ES) of the benthic environment. These metrics were calculated from the recorded macrofaunal species abundance. The BENTIX indicator was calculated after Simboura \& Zenetos (2002), using an Add-In v09 (beta) software package for MS Excel 2003 (http://bentix.ath.hcmr. gr). The M-AMBI indicator developed by Muxika et al. (2007) was calculated with the software provided by these authors (http://ambi.azti.es/), using their classification of species (available since February 2010). The Shannon-Wiener diversity index $\left(H^{\prime}\right)$ (Shannon \& Weaver 1949), was calculated using the Primer software v6 (Plymouth Marine Laboratory). The benthic opportunistic polychaetes amphipods in-

Table 1. Sampling stations at 2 tuna fattening farms (codenamed TT and KIT) in Limassol Bay, Cyprus, distance from cages and bottom depth. REF: reference station, located 2 $\mathrm{km}$

\begin{tabular}{|lcc|}
\hline Station & Distance from cages $(\mathrm{m})$ & Depth $(\mathrm{m})$ \\
\hline TT & 0 & 66 \\
TT 50 & 50 & 60 \\
TT 250 & 250 & 59 \\
KIT & 0 & 66 \\
KIT 50 & 50 & 67 \\
KIT 250 & 250 & 66 \\
REF & $>250$ & 66 \\
\hline
\end{tabular}

dex (BOPA, Dauvin \& Ruellet 2007), which is based on the opportunistic polychaete/amphipod ratio was also calculated. Finally, the recently proposed BQI-family index was applied based on the formula developed by Dimitriou et al. (2012). Key species for the discrimination of populations between the stations were assigned a disturbance sensitivity value (according to the sensitivity values given by Dimitriou et al. 2012). These sensitivity values were inferred by the frequency of occurrence of each taxon (species or family in this case) along a gradient of benthic diversity; the assumption being that taxa which tend to occur in low diversity samples are probably more tolerant to disturbance than those occurring only in high diversity samples (Rosenberg et al. 2004, Dimitriou et al. 2012).

\section{Multivariate analyses}

Multivariate analyses were applied to macrobenthic assemblages derived from both total and $1 \mathrm{~mm}$ sieves using the Primer software package v6. Nonmetric Multi-Dimensional Scaling (MDS) ordination analysis was applied in this study using the BrayCurtis coefficient in order to obtain a 2D plot of spatial and temporal changes in macrobenthic community structure at each of the stations studied. In order to downweigh the contribution of the abundant/common species in our analysis, a square root transformation of the raw data was used. SIMPER analysis was used to evaluate the contribution of each species to the average Bray-Curtis dissimilarity of the stations. The analysis was also used to identify the species which contributed most to the intra-station similarity among the replicates of each station.

\section{RESULTS}

\section{Spatial patterns}

MDS analysis of species abundance data obtained from the use of both $1 \mathrm{~mm}$ and total sieve showed no strong gradient in the macrobenthic samples of the total sieve data (Fig. 2a), but rather an aggregation of samples obtained from the 2 fish farms as 2 clusters (with $40 \%$ similarity) around the 3 reference samples. Major differentiation was observed in the macrobenthic assemblages obtained from the second replicate of the station KIT 250, which showed quite low species richness. The MDS analysis with macrofaunal data obtained with $1 \mathrm{~mm}$ sieve showed similar results (Fig. 2b). 


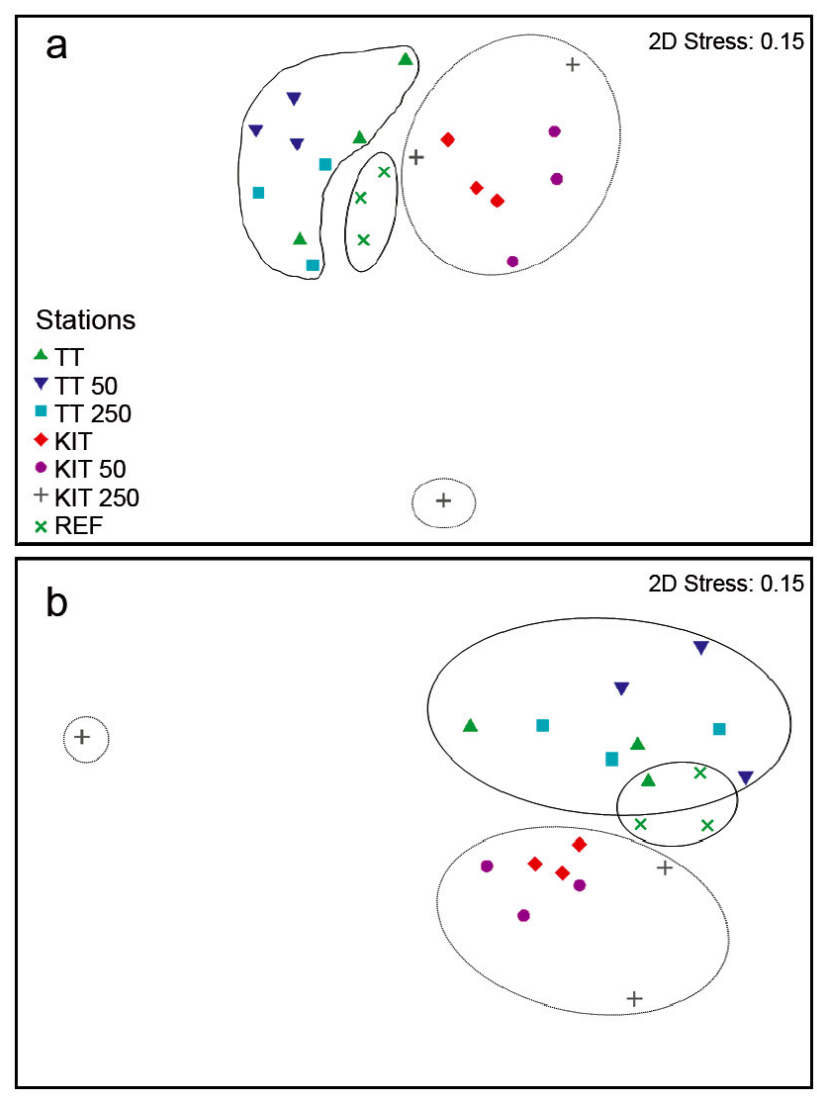

Fig. 2. Non-metric multidimensional scaling ordination plots of species abundance in macrobenthic samples sieved through different mesh sizes: (a) 'total sieve' (i.e. results from 1 and $0.5 \mathrm{~mm}$ sieves combined) and (b) $1 \mathrm{~mm}$ sieve. See Table 1 for details on sampling stations. Data were squareroot transformed. Resemblance: S17 Bray-Curtis similarity

\section{Biotic indices}

The ES for each sample was calculated by means of macrobenthic indices for both total and $1 \mathrm{~mm}$ sieve (Fig. 3). Each indicator showed a similar pattern of response for the 2 different sieve mesh sizes, although in most cases different numerical values were recorded. Among the 7 stations and the total of 21 replicates examined, only 2 were not of acceptable (i.e. 'high' or 'good') ES according to the WFD. The BOPA index characterized all the samples as 'high' or 'good'. H' , M-AMBI and BQI-family assigned acceptable labels (i.e. 'high' or 'good') to 20 of the replicates; whereas 1 replicate from KIT 250 was rated 'poor' to 'moderate', depending on the indicator used and on the sieve mesh size. BENTIX assigned 'unacceptable' ecological status in the WFD context to 3 replicates (one each from TT, KIT 250 and REF), which were classified as 'moderate' or 'poor'. However, BENTIX results for these 3 replicates were not reliable, as more than $20 \%$ of the total abundance of the sample belonged to species that were not used for the calculation of the index.

Comparison among indicators obtained from the same sample from sieves with different mesh sizes (total sieve and $1 \mathrm{~mm}$ ) showed that there was a very strong correlation $(\mathrm{p}<0.01)$ between the 2 sieve fractions (Table 2). There was also quite strong agreement between the ES assigned by BQI-family and BOPA, and less agreement among $H^{\prime}$, BENTIX and M-AMBI. Major ES changes (i.e. the change between 'acceptable' and 'unacceptable' ES) were recorded only in the case of BENTIX (5\%).

The variability of the ES assigned by each indicator was also examined in the replicates of each station (Table 3). The majority of replicates within stations recorded a range of $2 \mathrm{ES}$ ('good and 'high') for both sieve fractions. It appears that variability slightly increases in $1 \mathrm{~mm}$ mesh sieve data, as most indicators presented a larger range of classification between replicates for this data, compared with total sieve data. The BOPA index was the most homogenous in ecological assessment, assigning the same ES to all replicates for total sieve data and giving results within a range of $2 \mathrm{ES}$ for $1 \mathrm{~mm}$ sieve data. Results obtained for M-AMBI and BENTIX and $H^{\prime}$ were more variable, with ranges of 3 ES between replicates in some cases; those obtained by BOPA and BQI-family were less variable, unaffected by the sieve mesh size, and giving ranges of 1 or 2 between replicates. Overall, the average value of the ES classification among the replicates of each station was below or equal to 2 (Table 3 ).

\section{Benthic communities}

SIMPER analysis (Table 4) showed that the macrobenthic assemblages that typify the stations are diverse and consist of a variety of organisms, mainly polychaetes, molluscs, crustaceans, echinoderms and sipuncula. The majority of taxa that are responsible for the dissimilarities among the stations are assigned values representing moderate sensitivity to disturbance. Only a few taxa (Apseudes talpa, Apseudopsis latreilii, Cirratulus sp. and Corbula gibba) had low sensitivity values. However, these taxa were found both at stations under the cages (TT and KIT) and those far from them (KIT 50, KIT 250 and REF); therefore, their appearance cannot be attributed to organic enrichment due to the fish farms. The analysis was performed in order to compare the relationships in terms of the macrofaunal 

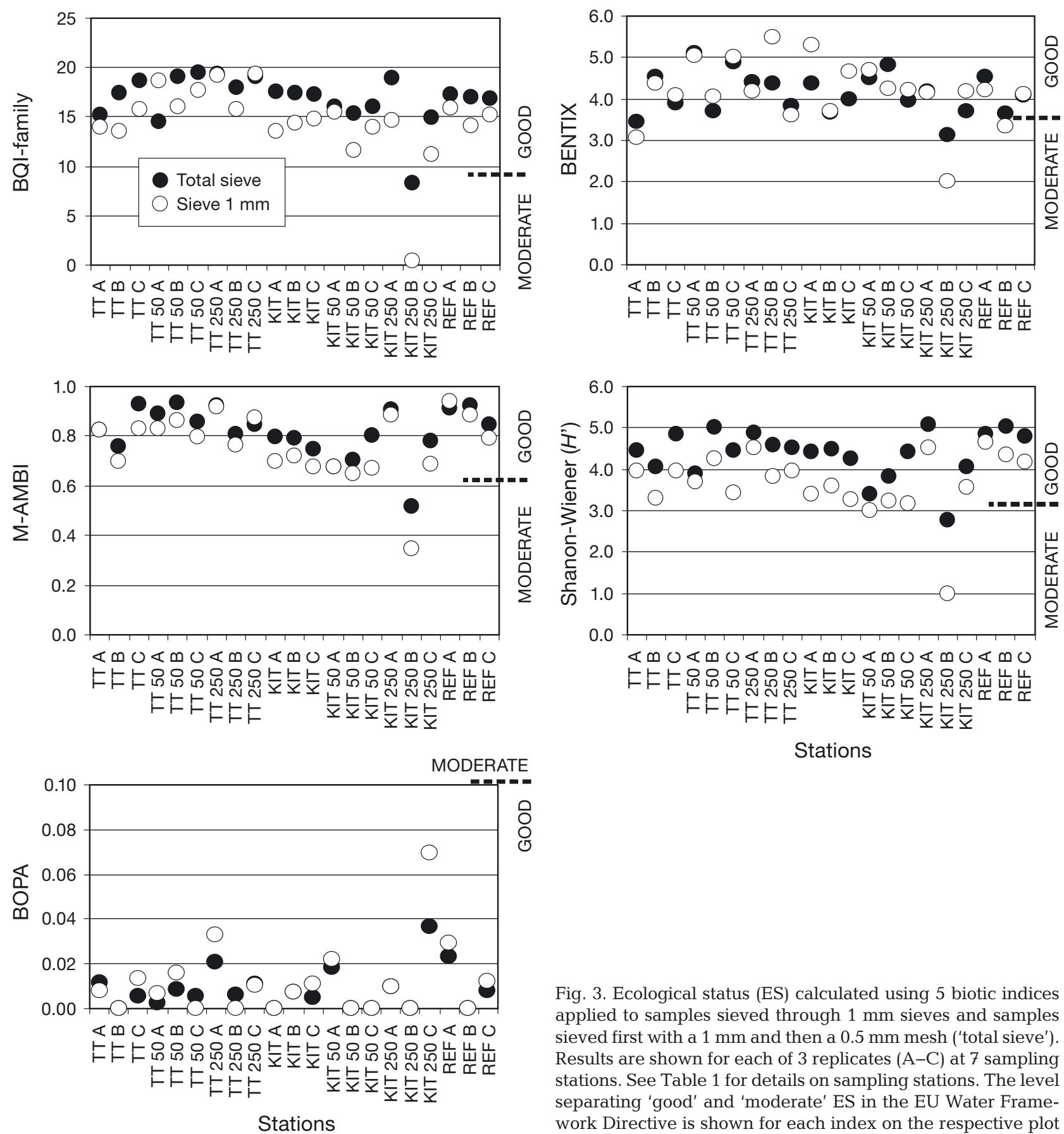

Stations

Fig. 3. Ecological status (ES) calculated using 5 biotic indices applied to samples sieved through $1 \mathrm{~mm}$ sieves and samples sieved first with a $1 \mathrm{~mm}$ and then a $0.5 \mathrm{~mm}$ mesh ('total sieve'). Results are shown for each of 3 replicates $(A-C)$ at 7 sampling stations. See Table 1 for details on sampling stations. The level separating 'good' and 'moderate' ES in the EU Water Framework Directive is shown for each index on the respective plot

assemblages between the stations near the cages and the other stations at each fish farm. As shown in Table 4, the dissimilarity values derived from the analysis were relatively similar (ranging from 55.52 to 65.24), indicating that the benthic community structure is not strongly affected by the activities carried out by the 2 fish farms. To a large extent, the differences among stations reflect natural variability rather than organic enrichment gradients.

\section{DISCUSSION}

Our results showed that the benthic effects of tuna farming in Cyprus were insignificant since the majority the samples were found to be of 'good' or 'high' ES according to the indicators used (Fig. 3), unlike other types of fish farming in the Mediterranean where significant impacts beneath and in the close vicinity of fish farms have been found (Karakassis et 
Table 2. Assessment of ecological status (ES) of the benthic environment in the vicinity of tuna fattening farms calculated using 5 biotic indices: comparison of indicators using macrobenthic samples $(\mathrm{N}=21$ ) obtained with a $1 \mathrm{~mm}$ mesh with their 'total sieve' counterparts, i.e. samples sieved first with a $1 \mathrm{~mm}$ and then a $0.5 \mathrm{~mm}$ mesh. 'Major ES change' refers a change from 'acceptable' to 'unacceptable' ES between the 2 sieve treatments. ${ }^{* *} \mathrm{p}<0.01$.

\begin{tabular}{|lccc|}
\hline Biotic index & $\begin{array}{c}\text { Spearman } \\
\mathrm{r}\end{array}$ & $\begin{array}{c}\text { Change } \\
\text { in ES } \\
(\%)\end{array}$ & $\begin{array}{c}\text { Major ES } \\
\text { change } \\
(\%)\end{array}$ \\
\hline BENTIX & $0.808^{* *}$ & 38 & 5 \\
BQI-family & $0.594^{* *}$ & 5 & 0 \\
M-AMBI & $0.896^{* *}$ & 24 & 0 \\
Shannon-Wiener $\left(H^{\prime}\right)$ & $0.884^{* *}$ & 57 & 0 \\
BOPA & $0.838^{* *}$ & 5 & 0 \\
\hline
\end{tabular}

al. 2000, 2002, Lampadariou et al. 2005, Tomassetti et al. 2009, Papageorgiou et al. 2010). Our results are partly in agreement with previous studies at the Cyprus coast on seabream and seabass cage farms, where no serious environmental impacts were recorded and all stations were classified as 'moderate' or 'good' (Forchino 2010, Simboura \& Argyrou 2010). This lack of significant negative impacts of fish farms in Cyprus may be attributed to the fact that they are all located in relatively exposed sites, in waters deeper than $60 \mathrm{~m}$ and at a distance $\geq 1.5 \mathrm{~km}$ from the shore, i.e. characterized as 'off coast' and 'offshore' farms in the Holmer (2010) typology. Similar results to the present study were found in another study focusing on environmental impacts of tuna farming (Vezzulli et al. 2008) in SW Italy which used meiofauna and benthic bacterial communities as biotic indicators: that study did not detect any impact of organic wastes among the stations located near the cages or at the control site. On the other hand, Vita \& Marin (2007) monitored a tuna farm located at a depth of $32 \mathrm{~m}$ and found detectable benthic changes

Table 3. Variability in ecological status (ES) at sampling stations calculated using 5 biotic indices among replicate 'total sieve' and $1 \mathrm{~mm}$ sieve samples ( $\mathrm{N}=3$ replicates at each station)

\begin{tabular}{|lccccc|}
\hline \multirow{2}{*}{ Biotic index } & \multicolumn{3}{c}{ Total sieve } & & \multicolumn{2}{c|}{1 mm sieve - } \\
\cline { 2 - 3 } \cline { 5 - 6 } & of ES & $\begin{array}{c}\text { Avg. number } \\
\text { of ES levels }\end{array}$ & & $\begin{array}{c}\text { Range } \\
\text { ES }\end{array}$ & $\begin{array}{c}\text { Avg. number } \\
\text { of ES levels }\end{array}$ \\
\hline BENTIX & $1-3$ & 1.86 & & 2 & 2.00 \\
BQI-family & $1-2$ & 1.14 & & $1-2$ & 1.14 \\
M-AMBI & $1-3$ & 2.00 & & $1-3$ & 2.00 \\
Shannon-Wiener $\left(H^{\prime}\right)$ & $1-2$ & 1.43 & & $1-3$ & 1.57 \\
BOPA & 1 & 1.00 & & $1-2$ & 1.14 \\
\hline
\end{tabular}

up to $200 \mathrm{~m}$ from the edge of the cages, including some very severe ones, with abundant capitellids present up to $5 \mathrm{~m}$ from the edge of the cages. Our results were similar to the findings of Borja et al. (2009) for the tuna farm in Garrucha (on the Spanish Mediterranean Coast) with similar depths (53 to $62 \mathrm{~m}$ ) and current speed (14 $\mathrm{cm} \mathrm{s}^{-1}$, compared with 10 to $35 \mathrm{~cm} \mathrm{~s}^{-1}$ in Cyprus). As in Cyprus there was no change at this site in macrofaunal diversity or in the values of the indicators used with distance from the farm.

Besides bottom depth, distance and exposure to wave action, the impacts of tuna farms in Cyprus are probably reduced because the fallowing period is probably long enough (December to June) for the system to recover. In more sheltered and shallow locations recovery has been shown to take a long time, probably $>2$ yr (Karakassis et al. 1999). However in Cyprus the combination of the exposed nature of the farming site and periodic fallowing allows the maintenance of a good ES.

One of the objectives of the present study was to test whether sampling macrofauna with sieves of different mesh sizes affects the assessment of ES. Regarding the benthic indicators, it was initially expected that the Shannon-Wiener index would record higher values, indicating high diversity in the total sieve; the BOPA index was expected to record higher values indicating degraded conditions; and the $\mathrm{M}$ AMBI, BQI-family and BENTIX indices were expected to record lower values, also indicating more degraded conditions in the total sieve fraction. From the comparison of the indices used, as shown in Table 2 , there is a significant correlation $(p<0.01)$ between values of each index for the 2 mesh sizes. We can thus conclude that valid results can be extracted using $1 \mathrm{~mm}$ mesh sieve in benthic community analysis.

Due to the 'acceptable' (i.e. 'good' and 'high' ES) ecological conditions of the area (Fig. 3), no small opportunistic species such as Capitella capitata were found (Table 4 ). The use of a small mesh screen is appropriate when size classes are important, i.e. when small opportunistic species or juveniles are present (Rees 1984). This is often the case for studies of global benthic enrichment (Pearson \& Rosenberg 1978) and sediments beneath fish farms (Karakassis et al. 2000). It has been shown that the ratio of macrofaunal biomass obtained through sieving with $0.5 \mathrm{~mm}$ over that of $1.0 \mathrm{~mm}$ de- 
Table 4. SIMPER analysis results performed on total sieve data (in each comparison only the 7 species contributing most to the dissimilarity are shown). Average abundance and percentage contributions of each species to dissimilarities between pairs of sampling stations. Contr.: Contribution. Taxa recorded were Polychaeta (P), Mollusca (M), Crustacea (C), Sipuncula (S) and Echinodermata (E). $f$ : the sensitivity value was inferred from the family level

\begin{tabular}{|c|c|c|c|c|c|c|}
\hline \multirow[t]{3}{*}{ Taxon } & \multirow[t]{3}{*}{ Species } & \multicolumn{5}{|c|}{ Dissimilarity between pairs of stations } \\
\hline & & \multicolumn{2}{|c|}{ _ Avg. abundance } & \multirow{2}{*}{$\begin{array}{l}\text { Contr. to } \\
\text { dissimilarity }\end{array}$} & \multirow[t]{2}{*}{ Cum. $(\%)$} & \multirow{2}{*}{$\begin{array}{c}\text { Sensitivity } \\
\text { value }\end{array}$} \\
\hline & & 1st group & 2nd group & & & \\
\hline \multicolumn{7}{|c|}{ Groups TT \& TT 50. Average dissimilarity: 59.26} \\
\hline $\mathrm{E}$ & Amphipholis squamata & 0 & 2.96 & 2.61 & 4.40 & 12.33 \\
\hline $\mathrm{C}$ & Galathea sp. & 1.63 & 3.48 & 2.12 & 7.98 & $22.00 f$ \\
\hline $\mathrm{P}$ & Eunice oerstedii & 0.67 & 2.51 & 1.77 & 10.97 & $16.00 \mathrm{f}$ \\
\hline M & Anodontia fragilis & 2.26 & 0.58 & 1.67 & 13.78 & 12.96 \\
\hline M & Myrtea spinifera & 1.86 & 0 & 1.66 & 16.59 & 13.55 \\
\hline $\mathrm{P}$ & Hyalinoecia fauveli & 2.6 & 0.91 & 1.58 & 19.25 & $20.00 f$ \\
\hline $\mathrm{S}$ & Onchnesoma steenstrupii & 1.63 & 1.41 & 1.30 & 21.44 & 13.37 \\
\hline \multicolumn{7}{|c|}{ Groups TT \& TT 250. Average dissimilarity: 56.46} \\
\hline M & Anodontia fragilis & 2.26 & 0.33 & 1.75 & 3.10 & 12.96 \\
\hline $\mathrm{C}$ & Galathea sp. & 1.63 & 2.67 & 1.75 & 6.20 & $22.00 f$ \\
\hline $\mathrm{P}$ & Paradoneis harpagonea & 0.94 & 2.64 & 1.67 & 9.16 & 12.56 \\
\hline $\mathrm{S}$ & Onchnesoma steenstrupii & 1.63 & 1.91 & 1.60 & 12.00 & 13.37 \\
\hline M & Myrtea spinifera & 1.86 & 0.33 & 1.39 & 14.45 & 13.55 \\
\hline $\mathrm{P}$ & Glycera tesselata & 1.79 & 0.58 & 1.22 & 16.61 & 18.00 \\
\hline $\mathrm{P}$ & Syllis garciai & 0.33 & 1.62 & 1.2 & 18.74 & $11.00 \mathrm{f}$ \\
\hline \multicolumn{7}{|c|}{ Groups TT \& REF. Average dissimilarity: 58.03} \\
\hline M & Thyasira flexuosa & 1.11 & 1.91 & 1.78 & 3.07 & 10.45 \\
\hline $\mathrm{S}$ & Aspidosiphon muelleri kovalevskii & 0 & 1.8 & 1.66 & 5.94 & 13.15 \\
\hline $\mathrm{C}$ & Apseudes talpa & 0.94 & 2.4 & 1.49 & 8.50 & $8.90 f$ \\
\hline M & Anodontia fragilis & 2.26 & 1.15 & 1.38 & 10.88 & 12.96 \\
\hline $\mathrm{C}$ & Galathea sp. & 1.63 & 0.58 & 1.34 & 13.19 & $22.00 f$ \\
\hline $\mathrm{P}$ & Euclimene oerstedi & 0 & 1.28 & 1.28 & 15.40 & 18.82 \\
\hline $\mathrm{P}$ & Magelona minuta & 1.46 & 0.33 & 1.27 & 17.59 & 18.41 \\
\hline \multicolumn{7}{|c|}{ Groups KIT \& KIT 50. Average dissimilarity: 55.52} \\
\hline $\mathrm{M}$ & Thyasira flexuosa & 2.41 & 0 & 3.11 & 5.60 & 10.45 \\
\hline $\mathrm{P}$ & Cirratulus sp. & 2.77 & 0.58 & 2.94 & 10.91 & $7.00 \mathrm{f}$ \\
\hline $\mathrm{P}$ & Paradoneis harpagonea & 1.28 & 0 & 1.65 & 13.88 & 12.56 \\
\hline $\mathrm{P}$ & Asychis biceps & 1.91 & 0.67 & 1.55 & 16.66 & 20.95 \\
\hline $\mathrm{C}$ & Paguridae & 0.94 & 0.67 & 1.47 & 19.31 & $12.00 \mathrm{f}$ \\
\hline M & Corbula gibba & 2.51 & 1.47 & 1.43 & 21.88 & 4.84 \\
\hline $\mathrm{P}$ & Hyalinoecia brementi & 2.72 & 1.89 & 1.28 & 24.19 & $20.00 f$ \\
\hline \multicolumn{7}{|c|}{ Groups KIT \& KIT 250. Average dissimilarity: 65.24} \\
\hline $\mathrm{P}$ & Hyalinoecia fauveli & 3.27 & 0.58 & 3.66 & 5.62 & $20.00 f$ \\
\hline $\mathrm{P}$ & Cirratulus sp. & 2.77 & 0.58 & 3.02 & 10.25 & $7.00 \mathrm{f}$ \\
\hline M & Corbula gibba & 2.51 & 0.33 & 2.81 & 14.56 & 4.84 \\
\hline M & Nuculana pella & 2.06 & 1.44 & 2.02 & 17.65 & 13.55 \\
\hline $\mathrm{P}$ & Hyalinoecia brementi & 2.72 & 1.55 & 1.94 & 20.63 & $20.00 f$ \\
\hline $\mathrm{C}$ & Apseudopsis latreillii & 0 & 1.52 & 1.93 & 23.59 & 10.01 \\
\hline M & Thyasira flexuosa & 2.41 & 1.15 & 1.83 & 26.40 & 10.45 \\
\hline \multicolumn{7}{|c|}{ Groups KIT \& REF. Average dissimilarity: 58.58} \\
\hline $\mathrm{C}$ & Apseudes talpa & 0 & 2.40 & 2.33 & 3.98 & $8.90 f$ \\
\hline $\mathrm{P}$ & Cirratulus sp. & 2.77 & 0.67 & 2.23 & 7.80 & $7.00 \mathrm{f}$ \\
\hline M & Nuculana pella & 2.06 & 0 & 2.06 & 11.32 & 13.55 \\
\hline $\mathrm{C}$ & Paguridae & 0.94 & 2.58 & 1.89 & 14.54 & $12.00 f$ \\
\hline M & Corbula gibba & 2.51 & 0.67 & 1.82 & 17.65 & 4.84 \\
\hline $\mathrm{S}$ & Aspidosiphon muelleri kovalevskii & 0 & 1.80 & 1.66 & 20.49 & 13.15 \\
\hline $\mathrm{P}$ & Hyalinoecia brementi & 2.72 & 1.24 & 1.46 & 22.98 & $20.00 f$ \\
\hline
\end{tabular}


creases with distance from the farm (Lampadariou et al. 2008) However, in the present study, major changes in ES when a larger mesh size was used were recorded only by BENTIX (5\%) and this result was an exception, since all the other indicators recorded no major changes in ES (Table 2). The benthic communities consisted of species with moderate sensitivity to disturbance (Table 4) and not of the typical opportunistic assemblages present in organically enriched ecosystems. The few taxa that are characterized by low sensitivity values (sensu Dimitriou et al. 2012) appeared in low abundance at almost all stations, indicating that fish farming activities were not affecting the spatial patterns of these taxa. The comparison of the dissimilarity values among stations verified these results, as most stations appeared to be equally dissimilar and the range of values is relatively small (55.52 to 65.24). Therefore, fish farming activities did not seem to significantly affect the structure of macrobenthic communities. The MDS ordination showed similar results for both total sieve and $1 \mathrm{~mm}$ sieve analysis (Fig. 2). Similarly, no differences between the MDS ordinations for the same 2 sieve fractions were recorded by Thompson et al. (2003).

Our results agree with those of several studies that have recommended the use of a $1 \mathrm{~mm}$ mesh sieve for ES assessment in an area impacted by anthropogenic activities, since the extra information retained by sieving with $0.5 \mathrm{~mm}$ mesh did not improve the ability to detect differences between potentially impacted areas and control stations (Hartley 1982, Karakassis \& Hatziyanni 2000, Lampadariou et al. 2005). However, in a similar study conducted in estuarine environments, Couto et al. (2010) found that all indicators were significantly different for the 2 mesh sizes and that the $0.5 \mathrm{~mm}$ mesh sieve captured more information about the studied system. Yet, the authors of that study attributed the differences between the sieving efficiencies to various factors (such as sampling season, habitat type, and the size of the organisms) and suggested that the ES classifications obtained from the $1 \mathrm{~mm}$ mesh sieve could be used after appropriate modifications are made to reference conditions and class boundary thresholds.

Our results showed that different replicates from the same station are likely to give different assessments of ES, which is an indication that analysis of only one sample is not a safe practice for monitoring (Table 3). These findings agree with Mavrič et al. 2013, who suggested that single samples (with a sampling area of $0.1 \mathrm{~m}^{2}$ ) are inappropriate for ES assessment at the Gulf of Trieste. In the Eastern Medi- terranean, Simboura et al. (2005) and Simboura \& Reizopoulou (2007) applied the BENTIX index to macrobenthic assemblage data derived from 2 replicate samples. In our study, the average ranges of ES classifications among replicates were between 1 and 2 (Table 3). Although in some cases 3 different statuses were recorded among replicates, these were exceptions. Most of the stations in the present study were assigned 2 ES classifications ('good' or 'high') for both sieve fractions, and no major changes were detected. This suggests, in agreement with Mavrič et al. 2013, that 2 replicates can provide fairly accurate results in an ecological assessment. However,in this context, an alternative would be to obtain more replicates using indices requiring less taxonomic effort for sample processing.

The tuna fattening industry has received a lot of criticism regarding the wastage of fish feed and fish oil and this very lucrative business is often regarded as ecologically inefficient (Vitalini et al. 2010), in common with a large proportion of marine finfish aquaculture (Duarte et al. 2009). However, it would be economically viable for this business to move to such offshore locations (as in the case of Cyprus) where benthic impacts are considerably less pronounced than those of coastal cage aquaculture.

Acknowledgements. We are grateful to 2 anonymous reviewers for their comments and suggestions on the initial version of the paper.

\section{LITERATURE CITED}

Aksu M, Kaymakçi-Başaran A, Egemen Ö (2010) Long-term monitoring of the impact of a capture-based bluefin tuna aquaculture on water column nutrient levels in the eastern Aegean Sea, Turkey. Environ Monit Assess 171: 681-688

Apostolaki ET, Tsagaraki T, Tsapakis M, Karakassis I (2007) Fish farming impact on sediments and macrofauna associated with seagrass meadows in the Mediterranean. Estuar Coast Shelf Sci 75:408-416

Başaran F, Özden O (2004) The investigation of the rearing of bluefin tuna (Thunnus thynnus, Linnaeus 1758) on culture conditions. Ege J Fish Aquat Sci 21:343-348

> Borja A, Franco J, Pérez V (2000) A marine biotic index to establish the ecological quality of soft-bottom benthos within European estuarine and coastal environments. Mar Pollut Bull 40:1100-1114

Borja A, Mader J, Muxica I, Rodríguez JG, Bald J (2008) Using M-AMBI in assessing benthic quality within the Water Framework Directive: some remarks and recommendations. Mar Pollut Bull 56:1337-1379

> Borja A, Rodriguez JG, Black K, Bodoy A and others (2009) Assessing the suitability of a range of benthic indices in the evaluation of environmental impact of fin and shellfish aquaculture located in sites across Europe. Aquaculture 293:231-240 
Cheshire A, Westphalen G, Kildea T, Smart A, Clarke S (1996) Investigating the environmental effect of sea-cage tuna farming. II. The effects of sea-cages. South Australian Research and Development Institute, Adelaide

Couto T, Patrício J, Neto JM, Ceia FR, Franco J, Marques JC (2010) The influence of mesh size in environmental quality assessment of estuarine macrobenthic communities. Ecol Indic 10:1162-1173

- Dauvin JC, Ruellet T (2007) Polychaete/amphipod ratio revisited. Mar Pollut Bull 55:215-224

de-la-Ossa-Carretero JA, Simboura N, Del-Pilar-Ruso Y, Pancucci-Papadopoulou MA, Giménez-Casalduero F, Sánchez-Lizaso JL (2012) A methodology for applying taxonomic sufficiency and benthic biotic indices in two Mediterranean areas. Ecol Indic 23:232-241

> Dimitriou PD, Apostolaki ET, Papageorgiou N, Reizopoulou S, Simboura N, Arvanitidis C, Karakassis I (2012) Metaanalysis of a large data set with Water Framework Directive indicators and calibration of a Benthic Quality Index at the family level. Ecol Indic 20:101-107

> Duarte CM, Holmer M, Olsen Y, Soto D and others (2009) Will the oceans help feed humanity? Bioscience 59: 967-976

FAO (Food and Agriculture Organization of the United Nations) (2004) Capture-based aquaculture. The fattening of eels, groupers, tunas and yellowtails. FAO, Rome

Fernandes M, Lauer P, Cheshire A, Angove M (2007a) Preliminary model of nitrogen loads from southern bluefin tuna aquaculture. Mar Pollut Bull 54:1321-1332

Fernandes M, Angove M, Sedawie T, Cheshire A (2007b) Dissolved nutrient release from solid wastes of southern bluefin tuna (Thunnus maccoyii, Castelnau) aquaculture. Aquacult Res 38:388-397

Ferraro SP, Cole FA (1990) Taxonomic level and sample size sufficient for assessing pollution impacts on the Southern California Bight macrobenthos. Mar Ecol Prog Ser 67: 251-262

Fleischer D, Gremare A, Labrune C, Rumohr H, Vanden Berghe E, Zettler ML (2007) Performance comparison of two biotic indices measuring the ecological status of water bodies in the southern baltic and gulf of Lions. Mar Pollut Bull 54:1598-1606

Forchino AA (2010) Development and application of a marine biotic index for the evaluation of the influence of aquaculture activities on the benthic ecosystem in Mediterrenean coastal areas. PhD dissertation, University of Insubria, Varese

Forrestal F, Coll M, Die DJ, Christensen V (2012) Ecosystem effects of bluefin tuna Thunnus thynnus thynnus aquaculture in the NW Mediterranean Sea. Mar Ecol Prog Ser 456:215-231

Gowen RJ, Weston DP, Ervik A (1991) Aquaculture and the benthic environment: a review. In: Cowey CB, Cho CY (eds) Nutritional strategies and aquaculture waste. Proc 1st Int Symp Nutritional Strategies in Management of Aquaculture Waste. University of Guelph, Guelph, p 187-205

Gray JS (1981) The ecology of marine sediments. Cambridge University Press, Cambridge

- Gray JS, Aschan M, Carr MR, Clarke KR and others (1988) Analysis of community attributes of the benthic macrofauna of Frierfjord/Langesundfjord and in a mesocosm experiment. Mar Ecol Prog Ser 46:151-165

Hartley JP (1982) Methods for monitoring offshore macrobenthos. Mar Pollut Bull 13:150-154
Holby O, Hall POJ (1991) Chemical fluxes and mass balances in a marine fish cage farm. II. Phosphorus. Mar Ecol Prog Ser 70:263-272

> Holmer M (2010) Environmental issues of fish farming in offshore waters: perspectives, concerns and research needs. Aquacult Environ Interact 1:57-70

Karakassis I (2001) Ecological effects of fish farming in the Mediterranean. Cah Options Méditerranéennes 55: $15-22$

Karakassis I, Hatziyanni E (2000) Benthic disturbance due to fish farming analyzed under different levels of taxonomic resolution. Mar Ecol Prog Ser 203:247-253

Karakassis I, Hatziyanni E, Tsapakis M, Plaiti W (1999) Benthic recovery following cessation of fish farming: a series of successes and catastrophes. Mar Ecol Prog Ser 184: 205-218

- Karakassis I, Tsapakis M, Hatziyanni E, Papadopoulou KN, Plaiti W (2000) Impact of cage farming of fish on the seabed in three Mediterranean coastal areas. ICES J Mar Sci 57:1462-1471

Karakassis I, Tsapakis M, Smith CJ, Rumohr H (2002) Fish farming impacts in the Mediterranean studied through sediment profiling imagery. Mar Ecol Prog Ser 227: 125-133

> Labrune C, Amouroux JM, Sarda R, Dutrieux E, Thorin S, Rosenberg R, Grémare A (2006) Characterization of the ecological quality of the coastal gulf of lions (NW Mediterranean). A comparative approach based on three biotic indices. Mar Pollut Bull 52:34-47

Lampadariou N, Karakassis I, Pearson TH (2005) Cost/benefit analysis of a benthic monitoring programme of organic benthic enrichment using different sampling and analysis methods. Mar Pollut Bull 50:1606-1618

Lampadariou N, Akoumianaki I, Karakassis I (2008) Use of the size fractionation of the macrobenthic biomass for the rapid assessment of benthic organic enrichment. Ecol Indic 8:729-742

Madigan S, Clarke S, Haskard K (2001) Southern bluefin tuna (Thunnus maccoyii) environmental monitoring report: licence-based monitoring review and recommendations. South Australian Research and Development Institute, Adelaide

Matijević S, Kušpilić G, Barić A (2006) Impact of a fish farm on physical and chemical properties of sediment and water column in the middle Adriatic sea. Fresenius Environ Bull 15:1058-1063

Mavrič B, Urbanič G, Lipej L, Simboura N (2013) Influence of sample size on ecological status assessment using marine benthic invertebrate-based indices. Mar Ecol 34: 72-79

> Muxika I, Borja Á, Bald J (2007) Using historical data, expert judgement and multivariate analysis in assessing reference conditions and benthic ecological status, according to the European Water Framework Directive. Mar Pollut Bull 55:16-29

> Olsgard F, Somerfield PJ, Carr MR (1997) Relationships between taxonomic resolution and data transformations in analyses of a macrobenthic community along an established pollution gradient. Mar Ecol Prog Ser 149: 173-181

Ottolenghi F (2008) Capture-based aquaculture of bluefin tuna. In: Lovatelli A, Holthus PF (eds) Capture-based aquaculture. Global overview. FAO Fisheries Tech Pap 508. FAO, Rome, p 169-182

Papageorgiou N, Kalantzi I, Karakassis I (2010) Effects of 
fish farming on the biological and geochemical properties of muddy and sandy sediments in the Mediterranean Sea. Mar Environ Res 69:326-336

Pearson TH, Rosenberg R (1978) Macrobenthic succession in relation to organic enrichment and pollution of the marine environment. Oceanogr Mar Biol Annu Rev 16: 229-311

Rees HL (1984) A note on mesh selection and sampling efficiency in benthic studies. Mar Pollut Bull 15:225-229

Rosenberg R, Blomqvist M, Nilsson HC, Cederwall H, Dimming A (2004) Marine quality assessment by use of benthic species-abundance distributions: a proposed new protocol within the European Union Framework Directive. Mar Pollut Bull 49:728-739

Santulli A, Bertolino F, Asaro E, Lombardo S and others (2003) Environmental impact of a commercial farm of Mediterranean bluefin tuna (Thunnus thynnus) located in the Gulf of Castellammare (Trapani, Italy): preliminary results. Biol Mar Mediterr 10:477-481

Shannon CE, Weaver N (1949) The mathematical theory of communication. University of Illinois Press, Urbana, IL

Simboura N, Argyrou M (2010) An insight into the performance of benthic classification indices tested in eastern Mediterranean coastal waters. Mar Pollut Bull 60: 701-709

Simboura N, Reizopoulou S (2007) A comparative approach of assessing ecological status in two coastal areas of eastern Mediterranean. Ecol Indic 7:455-468

Simboura N, Zenetos A (2002) Benthic indicators to use in Ecological Quality classification of Mediterranean soft bottom marine ecosystems, including a new Biotic Index. Mediterr Mar Sci 3:77-111

Simboura N, Panayotidis P, Papathanasiou E (2005) A synthesis of the biological quality elements for the implementation of the European Water Framework Directive in the Mediterranean ecoregion: the case of Saronikos Gulf. Ecol Indic 5:253-266

Thompson BW, Riddle MJ, Stark JS (2003) Cost-efficient methods for marine pollution monitoring at Casey Station, East Antarctica: the choice of sieve mesh-size and taxonomic resolution. Mar Pollut Bull 46:232-243

Tomassetti P, Persia E, Mercatali I, Vani D, Marussso V, Por-

Editorial responsibility: Kenneth Black,

Oban, UK rello S (2009) Effects of mariculture on macrobenthic assemblages in a western Mediterranean site. Mar Pollut Bull 58:533-541

Vezzulli L, Chelossi E, Riccardi G, Fabiano M (2002) Bacterial community structure and activity in fish farm sediments of the Ligurian Sea (western Mediterranean). Aquacult Int 10:123-141

> Vezzulli L, Marrale D, Moreno M, Fabiano M (2003) Sediment organic matter and meiofauna community response to long-term fish-farm impact in the Ligurian Sea (western Mediterranean). Chem Ecol 19:431-440

> Vezzulli L, Pruzzo C, Fabiano M (2004) Response of the bacterial community to in situ bioremediation of organic-rich sediments. Mar Pollut Bull 49:740-751

- Vezzulli L, Moreno M, Marin V, Pezzati E, Bartoli M, Fabiano M (2008) Organic waste impact of capture-based Atlantic bluefin tuna aquaculture at an exposed site in the Mediterranean Sea. Estuar Coast Shelf Sci 78: 369-384

> Vita R, Marin A (2007) Environmental impact of capturebased bluefin tuna aquaculture on benthic communities in the western Mediterranean. Aquacult Res 38: 331-339

Vita R, Marín A, Jiménez-Brinquis B, Cesar A, Marín-Guirao L, Borredat M (2004) Aquaculture of bluefin tuna in the Mediterranean: evaluation of organic particulate wastes. Aquacult Res 35:1384-1387

Vitalini V, Benetti DD, Caprioli R, Forrestal F (2010) Northern blue fin tuna (Thunnus thynnus thynnus) fattening in the Mediterranean sea: status and perspectives. World Aquacult 41:30-36

> Vlek HE, Verdonschot PFM, Nijboer RC (2004) Towards a multimetric index for the assessment of Dutch streams using benthic macroinvertabrates. Hydrobiologia 516: 173-189

Warwick RM (1988) Analysis of community attributes of the macrobenthos of Frierfjord/Langesundfjord at taxonomic levels higher than species. Mar Ecol Prog Ser 46: $167-170$

- Wu RSS (1995) The environmental impact of marine fish culture: towards a sustainable future. Mar Pollut Bull 31: 159-166

Submitted: September 17, 2012; Accepted: April 17, 2013 Proofs received from author(s): June 3, 2013 